\title{
The Impact of Learning in Nature for The Well-being of Children with Special Needs
}

\author{
Melati Ismi Hapsari ${ }^{1}$, Lia Mareza ${ }^{2}$ \\ \{melshapsari@gmail.com¹, liamareza@ump.ac.id $\left.{ }^{2}\right\}$ \\ Department of Early Childhood Education, Faculty of Teacher Training \\ and Education, Universitas Muhammadiyah Purwokerto ${ }^{1}$, \\ Department of Elementary Education, Faculty of Teacher Training and \\ Education, Universitas Muhammadiyah Purwokerto ${ }^{2}$
}

\begin{abstract}
The high number of children with special needs in Indonesia requires serious handling from various parties. An accessible approach is needed for children from lower economic backgrounds, as well as for those in areas far from health and educational services. Learning activities in nature using natural media can be a good suggestion and solution. This study aims to examine the positive impacts of nature-based learning on the well-being of early-aged children with special needs. The method in this research is a one-shot experimental design. This study used a qualitative and descriptive technique to analyze the data. The results showed that learning carried out in nature can significantly improve children's well-being and their development achievement.
\end{abstract}

Key Words : Special Needs, Early Childhood, Learning in Nature, Children Well-being

\section{Introduction}

First of all it is important to underline what is or who are children with special needs ? Several experts prefer to use the term of special needs or exceptional children to replace the term of handicapped children or children with disability [1]. Moreover, they can be classified as follows: Mental Retardation, Autism, Learning Disability, Attention Deficit and Hyperactive Disorder, Emotional and Behavior Disorder, Speech and Language Disability, Visual Impairment, Hearing Impairment, Physical Disability, and Giftedness [2].

The prevalence of children with special needs tends to increase every year in many countries. However, there is still very limited data in Indonesia. This is due to the limited number of studies that specifically examine this problem. Based on a report from the World Health Organization (WHO) [3] there are around 4.2 million children with special needs in Indonesia, most of them were detected at an early age.

WHO [3] estimates that the number of children with disabilities is around $7-10 \%$ of the total population of children. Moreover, based on data from the 2012 Indonesian National Health Survey [4] the percentage of children with special needs in Indonesia is $81.81 \%$ at the primary school age level and below (Early Age), where overall only $14.4 \%$ are in educational institutions or taking therapy in private or government-owned rehabilitation centers.

The high number of children with special needs in Indonesia urge serious attention from various parties. Children with special needs have relatively different conditions of ability and potential development. These conditions could cause obstacles to several aspects of life such 
as academics, social communication, and the fulfillment of daily life activities. Therefore, special and inclusiveness services in education are really needed.

An adequate and appropriate service particularly in the educational field can help the children avoid and overcome their learning barriers, and can help them to be more adaptive in their society. Furthermore, it also can reduce the existing negative symptoms and maximize their potential optimally. This can affect the quality of life of children with special needs, and in general, it can give a positive impact on the development of Indonesian human resources.

The Indonesian government has paid great attention to the problems of children with special needs since a decade ago, especially through the policy of inclusive education. Banyumas Regency is one of the districts in Indonesia that has declared itself an inclusion district since 2016. The Banyumas Regency Education Office [5] noted that there were 2,962 children with special needs in this area who were successfully recorded. Furthermore, the Banyumas District Education Office designated 542 elementary schools as educational units that provide inclusive education services. There is at least one elementary school that provides inclusive education in each sub-district. However, other types of schools, including Early Childhood Education (PAUD) that have not been designated as providers of inclusive education services, are not allowed to refuse prospective students with special needs.

Unfortunately, as happened in many areas in Indonesia, the crucial problem is related to confusion toward teachers to provide inclusive services, especially at the level of preschool. Most preschool institutions are still unable to move away from monotonous learning activities that are more oriented towards academic achievement. This in turn makes it more difficult for children with special needs to achieve adequate developmental growth and therefore it makes them more difficult to adapt.

In Banyumas Regency, there are 810 preschools across 27 sub-districts, where each institution has at least one child with special needs on average. In addition, the quality of handling children with special needs in early childhood education institutions in the Banyumas district was generally at a moderate level [5]. In terms of quality, there needs to be an increase in the variety of learning activities that can accommodate children's development to be more optimal.

Based on these facts, there need to be holistic and integrated handling steps through integrated treatment with the education curriculum in schools, especially at the basic education level. The Indonesian government signed the convention on March 30th, 2007 in New York. This shows the seriousness of the Indonesian state to respect, protect, fulfill, and advance the rights of persons with disabilities, including in education services. In realizing an independent and quality education system as regulated in Law no. 20 of 2003 concerning the National Education System, it is necessary to make various strategic and integral efforts that support the implementation of education [6]. The opportunity to obtain quality education applies to all (Education for All) from early childhood to higher education.

On the other hand, there is a need for an approach that can be more easily accessed for children with special needs, especially those from the lower economic class, in rural areas, and far from health services, especially therapy services in clinics and hospitals. Various scientific literature discusses a lot about activities in nature and various natural media that can have a positive impact on children with special needs [7][8].

Several theories and research results find a significant relationship among children's interactions, the natural environment and a decrease in negative symptoms of children with special needs, as well as an increase in the quality of their mental health [9][10][11]. In addition, free play in the natural environment can improve the quality of children's social interaction as well as enthusiasm and ability to concentrate [12][13][14]. 
Many areas in Indonesia including Banyumas Regency, especially in rural areas, have many natural open spaces, such as rice fields, gardens, and rivers, along with various natural media such as plants, seeds, flowers, leaves, dry branches, and twigs, rocks. , gravel, water, sand, etc. which can be used as a learning medium as well as an integrated yet easy and inexpensive therapeutic tool for children with special needs in preschool.

In Banyumas Regency, a small number of preschools used nature as a learning setting and media, including for students with special needs. It is important to find the impact of learning in nature toward children with special needs, at least how the effectiveness on the well-being of the children. Therefore, these are the two aims of this study :

1) To find the effectiveness of learning in nature on the well-being of the children with special needs.

2) To identify what is the main factor in nature learning that affects the well-being of children with special needs.

\section{Method}

\subsection{Participants}

This study used a qualitative approach. The method used in this research is an experimental research method with the model of One-Shot Case Study in which a group was given treatment and the results were then observed. In this case, nature-based learning was the treatment as an independent variable. The dependent variables in this study are 1) The psychological well-being of early-aged children with special needs, 2) The developmental achievement of early-aged children with special needs.

Subjects

The subjects in this study were the students of a preschool named Taman Bermain Qaryah Thayyibah (TB QITA). Purposive sampling was applied in this study based on the reason that this institution has implemented nature-based learning activities for its students, where $60 \%$ of learning activities are done outdoors, particularly in nature. The research subjects were 3 children with special needs with relatively different diagnoses, symptoms, and developmental characteristics.

\subsection{Data Collection}

The data were collected through 3 main techniques :

1) Observation

Depth observation was held to the subjects, based on certain indicators of well-being : a) the emergence of positive emotion, i.e. happiness, excitement, and enthusiasm, with the score of the scale ranged from 0 as inadequate to 7 as adequate; b) the emergence of negative emotion, i.e sadness, anger, anxious, worried, scared, and frustration, with the score ranged from 0 as inappropriate to 7 as appropriate ; c) the decline of negative symptoms of the disorders. The negative symptoms measured in this study through observation were temper tantrum, aggressive or uncooperative behavior, lack of communication and interaction, not able to focus. 
Observation also focused on the improvement of the developmental milestone of the subjects on the whole aspects (cognitive, language, fine motor and gross motor skills, as well as social and emotional).

Moreover, the observation was delivered in several particular events : classroom learning activities, individual educational program, home visit activity.

2) Interview

Researchers conducted the in-depth interview toward the subjects, side by side with the observation. The interview also included the teachers and the parents. It aimed to explore more data about the well-being and the developmental milestone of subjects as above. It also enriched the important data to find what is the main factor of nature-based learning affected to the well-being of the subjects.

3) Documentation

Several supporting data were collected in this study, i.e. the instruments of curriculum, manual of learning activities, a list of student's names and detailed information, a report of the student's developmental milestone, a report and manual of therapy activity, and also the documents of the process and results of the treatment in the form of photos and videos.

\section{Result and Discussion}

\subsection{Description of Research Location and Subjects}

The location of the study was in a preschool which provided outdoor learning activity, and used nature as the setting and media of the learning activity. The location of the study was in that preschool named Taman Bermain Qaryah Thayyibah (TB QITA).

In TB QITA there were about $60 \%$ of learning activities delivered outdoors. Learning activities at this institution were carried out in a model of Beyond Centers and Circle Time (BCCT) which means there are approximately 8 to 12 children in one class, with several groups named Centers to facilitate various potentials and needs of children. The setting of the seat used a circle model, to provide maximum contact and interaction between teachers and students. The total number of students in TB QITA was 30, and 7 ones have neurodevelopmental disorders or special needs. The three children were taken randomly as research subjects.

The table below describes the three subjects and the information about the disorders.

Table 1. The Subjects and The Condition of Their Special Needs

\begin{tabular}{|c|c|c|c|c|}
\hline No. & Name & Gender & Age & Category of Special Needs \\
\hline 1. & AHM & Male & $6 y$ & Attention and hyperactivity disorder (ADHD) \\
\hline 2. & MRAF & Male & $5 \mathrm{y}$ & $\begin{array}{c}\text { General developmental delay which is caused by genetic multifactor } \\
\text { (cytomegalovirus, microcephaly, cerebral atrophy, bronchopneumonia, } \\
\text { right hearing loss } 90 \mathrm{db} \text { and left } 70 \mathrm{db} \text { ) }\end{array}$ \\
\hline 3. & AAZ & Male & $6 y$ & Down Syndrome \\
\hline
\end{tabular}


TB QITA with its vision of educating children to grow and to develop naturally provides a child-friendly curriculum. All of the learning activities were able to give maximum opportunity for children to move and explore their environment. Thus, the learning activities used several active learning methods, including exploring and experimenting outdoor, with natural media, and also in nature.

Children have five natural traits, namely full of amazement, high imagination, curiosity, high urge to ask questions, and being active with their full energy [15]. This is in line with the basic theory of cognitive development [16] that children are strong and motivated learners. This should be the basic knowledge for early childhood educators to be aware and able to present activities that can accommodate the nature of a child's development in harmony.

The teachers believe that every child has his or her own potential,and no exception for students with special needs. In addition, what educators must do is give children the opportunity to explore their potential in a real environment using all of their senses.

Likewise, the basic principle in the recent curriculum named, Kurikulum 2013 [17], that educational institution must emphasize meaningful learning activities through a scientific approach that allows children to observe, to use reasoning and logical thinking skills, to provide opportunities for children to participate directly in their environment and to discover new knowledge through exploring and experimenting, then to engage in active interaction and communication.

Another principle that is in line is the principle of Developmentally Appropriate Practice (DAP). The DAP principle emphasizes educators to fully realize that early childhood is unique. The application of learning must be able to accommodate and to facilitate the unique and different developmental needs of each child. Surely, this principle is also applied to early childhood with special needs [18].

In TB QITA, there are 5 centers, namely a center of preparation, a center of imagination, a center of design and creativity, a center of exploration, and a center for art and culture. The following is an overview of the plan for implementing daily learning (RPPH) which is implemented every Monday to Friday.

Table 2. The RPPH / The Agenda of Learning Activities

\begin{tabular}{|c|c|c|}
\hline TIMES & ACTIVITIES & SETTING \\
\hline $07.00-08.00$ & $\begin{array}{l}\text { Morning activity: morning journal, free } \\
\text { drawing, reading habit, recitation, phonics. }\end{array}$ & Outdoor \\
\hline $08.00-08.15$ & Conditioning & - \\
\hline 08.00-09.15 & $\begin{array}{l}\text { Gathering / classical, gymnastics (Tuesday \& } \\
\text { Thursday), Duha Prayer (Monday and } \\
\text { Wednesday) }\end{array}$ & Indoor, except for outdoor exercise \\
\hline $09.15-11.00$ & $\begin{array}{l}\text { Core activities, playing indoors, and outdoor } \\
\text { play activities. }\end{array}$ & Indoor and Outdoor \\
\hline $11.00-11.30$ & $\begin{array}{l}\text { Meal, toothbrush and preparation to go home } \\
\text { (praying and shaking hands) }\end{array}$ & Indoor and outdoor for toothbrushes \\
\hline
\end{tabular}

On Fridays, core activities are still carried out in a shorter duration then they return home earlier at 11.00. On Saturdays, there is no implementation of the central RPPH, or what is usually called a Special Day. Special day activities on Saturdays are focused on mastering children's life skills through several activities that are alternately done such as cooking, 
farming, community service activities in the schoolyard (such as coloring rocks, watering the schoolyard, collecting and disposing of dry leaf litter, etc.), outbound activities carried out in the environment around the school, riverbanks, role-playing activities in the schoolyard, etc. All activities on Saturdays are carried out almost completely outside the room (outdoor). The children and teachers carry out activities indoors only to prepare equipment or pray and opening activities at the beginning. Joint prayer activities can be even done outdoors.

The media used in learning activities at TB QITA is also commonly found and used in other preschools, for instance, various game tools (brick, block, Lego, and puzzle), various kinds of role-playing tools (dolls, miniature cooking tools, and miniature animals and vehicles), children's worksheets made by the teacher, and various reading cards and numbers.

The unique aspect of this school compared with many other preschools is the outdoor activities that are practiced a lot every day. The teachers of the school said that in general, at least $60 \%$ of outdoor activities are daily applied, through exploring activities, observing the natural surroundings, as well as doing experiments. Outdoor activities are carried out by schools to accommodate the natural development of children who tend to be active and like to move and to facilitate the absorption of richer information through natural phenomena and real events in the surrounding environment.

The media used in outdoor activities is more related to sensory motor activities, namely water, soil, rocks or gravel, grass and dry leaves, and flour or other sensory motor media. The teacher spreads a sitting mat, or arranges tables and chairs outside the room, under a big tree, and the children start to do learning activities. Storytelling activities are also often done outdoors. This is a challenge for the teachers because some very active children tend to be easily distracted.

Furthermore, children's concentration seems easier to be controlled outside the room during exploration and experimentation activities with natural materials. Exploration activities are carried out by looking for pebbles in groups or pairs, then counting with the stones, giving numbers, or making collages from collected stones. There are some other exploratory activities, such as finding insects around the school, looking for the plants they like the most, and then telling about them or applying them freely in pictures.

Classrooms in TB QITA are a bit different from preschools in general around Banyumas Regency. The classes at TB QITA are made in semi-open and semi-permanent, with a combination of walls and woven bamboo for the walls, wide windows, and doors that are always open, allowing the circulation of sunlight and air to come in and out freely. This is also intended so that children feel more free and comfortable because they are not confined to a closed room.

\subsection{Impacts on Children with Special Needs}

The method used in collecting research data was done by observation and interview. The improvement of child development is seen in five aspects, namely cognitive abilities, language skills, physical motor abilities (gross and fine motor skills), social-emotional abilities, and religious moral values. These aspects are shown through a checklist of child development compiled by researchers based on the level of achievement of early-aged children's development (ages 4-6 years) [17][19][20].

The subjects of this study were 3 children with developmental disabilities or special needs in TB QITA, respectively AHM, MRAF, and AAZ. The data collection techniques used were observation and structured interviews on the subject, teachers, and parents as additional data. The three research subjects have obtained nature-based learning activities at TB QITA 
for 1 semester, from July 2018 to July 2019. In April 2019 nature-based learning activities were carried out online due to the global COVID19 outbreak.

In the new academic year in July 2019, online learning activities are combined with independent therapy activities with media and outdoor settings, which are carried out by parents every day at home. Teachers and researchers provide training to parents, as well as measurements which are carried out online every Saturday. Individual therapy activities are given directly to children with special needs who come to the school twice a week.

As seen from the facts of the three research subjects, parents and teachers felt that there was a significant positive difference compared to when these kids first arrived at school. The three subjects showed more adequate positive emotional expressions (expressions of joy, great pleasure, enthusiasm). At the beginning of their coming to the school, MRAF and AAZ were still showing quite volatile emotional conditions, accompanied by several temper tantrums. Currently, the condition of the two subjects is much more conditioned and can be soothed during emotional moments. Another symptom that seems typical of both subjects is their behavior of ignorance or not responding to stimulation. Surprisingly, they have become much more responsive now.

From the beginning, AHM did not show emotional symptoms that were too heavy and seldom experienced temper tantrums. In the beginning, he was more likely to be indifferent. Now he is more able to express his feelings and ideas even though in a sentence structure that is still not clearly understood (improper articulation). Impulsivity can be seen from AHM. He will tend to do what he wants without considering his own or other people's danger. He is now much more cooperative and able to follow the instructions given.

The positive development shown by the three subjects above could be a natural condition of development that increases with the age of the child [21]. Early childhood growth and development runs dynamically with children's age from birth to adulthood. However, this certainly cannot be separated from the learning process or stimulation provided by the immediate environment, including the school [22].

The learning process provided by teachers in schools through nature-based activities that condition children to feel comfortable, safe, relaxed, and energized, of course, provides a positive role for biological growth and provides children with abilities new. Stimulation given to children that makes them feel happy is a pivotal factor for the brain and nerve system to grow optimally [22][24].

Furthermore, parents stated that they felt secure and comfortable while their children were at school. At school, children do not seem to feel constrained due to various daily activities and some activities that provide flexibility for children to move and discover new things. Children also appear enthusiastic when going to school. It can be seen from their positive emotional expressions such as smiling, expressing their cheerful and enthusiastic feeling. One of the participants, AHM, could even say "I like school", "I like friends", "I like toys and teachers at school".

The following is an illustration of the differences between the participants' conditions before and after the nature-based learning activities as a group for approximately 2 semesters. As stated before, this treatment was combined with individual therapy together with teachers who focused on the ability to follow instructions. 
Table 3. The Stage of Basal, Treatment, and Follow-up

\begin{tabular}{|c|c|c|c|}
\hline Name & Basal & Treatment & Follow-Up \\
\hline \multirow[t]{5}{*}{ AHM } & No tantrums & No tantrums & No tantrums \\
\hline & $\begin{array}{l}\text { Hitting his own head when } \\
\text { angry }\end{array}$ & $\begin{array}{l}\text { No more hitting his own head when } \\
\text { angry }\end{array}$ & $\begin{array}{l}\text { No more hitting his own head } \\
\text { when angry }\end{array}$ \\
\hline & Frequent & Occasional movements appear and & Repetitive movements appear with \\
\hline & Movements & stop when reminded several times & $\begin{array}{l}\text { little intensity (especially appear } \\
\text { when an activity is pausing) and }\end{array}$ \\
\hline & Not able to focus & $\begin{array}{l}\text { Started to focus, and willing to } \\
\text { follow orders }\end{array}$ & $\begin{array}{l}\text { stop when reminded. } \\
\text { Able to be more focused, willing } \\
\text { to follow orders, and more } \\
\text { cooperative }\end{array}$ \\
\hline \multirow[t]{5}{*}{ MRAF } & $\begin{array}{l}\text { Tantrums with typical } \\
\text { behavior of pulling clothes, } \\
\text { sitting down and refusing to } \\
\text { walk, intensity almost every } \\
\text { day } \\
\text { Not able to focus }\end{array}$ & $\begin{array}{l}\text { Tantrums with the same behavior, } \\
\text { reduced intensity still in } 1 \text { week }\end{array}$ & No tantrums \\
\hline & $\begin{array}{l}\text { Not understanding } \\
\text { commands }\end{array}$ & & \\
\hline & Not yet uttering sound or & Starting to be able to focus & Able to focus \\
\hline & words & Beginning to understand commands & Understand commands \\
\hline & & $\begin{array}{l}\text { Starting to appear minimal sounds } \\
\text { or words }\end{array}$ & $\begin{array}{l}\text { Sounds and words have come out } \\
\text { (the word "bola" is clearly uttered, } \\
\text { other words are not clear), and } \\
\text { trying to make voices and words } \\
\text { enthusiastically. }\end{array}$ \\
\hline \multirow[t]{5}{*}{ AAZ } & No tantrums & No tantrums & No tantrums \\
\hline & $\begin{array}{l}\text { Emotional behavior appears } \\
\text { frequently in everyday life }\end{array}$ & $\begin{array}{l}\text { Emotional behavior starts to } \\
\text { decrease }\end{array}$ & $\begin{array}{l}\text { Emotional behavior still appears } \\
\text { occasionally }\end{array}$ \\
\hline & Unwilling to focus & Starting to focus & Able to focus \\
\hline & understanding & Starting to understand commands & Able to understand commands \\
\hline & $\begin{array}{l}\text { commands } \\
\text { Following his own wishes }\end{array}$ & $\begin{array}{l}\text { Still following his own wishes, but } \\
\text { also listening to instructions }\end{array}$ & $\begin{array}{l}\text { Still following occasional his own } \\
\text { desire, willing to listen to } \\
\text { instructions, but still firmed }\end{array}$ \\
\hline
\end{tabular}

Based on the above description, in terms of quality, it appears that there was an improvement in psychological well-being in the three subjects. It was indicated by the decreasing expression of negative emotions, also by increasing the quality of positive emotional expressions. In addition, there was a significant difference in the attitudes and behavior of the three research subjects, in the current condition after the subject received stimulation of nature-based learning in TB QITA compared to before the subject entered the school. There was a general improvement in the quality of development.

In April 2020 due to the increasing COVID19 pandemic situation, the homeschooling policy was implemented. Online learning is then applied to all students including children with special needs. Even though the teacher had performed the learning activities in the online learning, they provided opportunities for students to participate actively and have interaction with the surrounding environment and nature around the house. However, the activities should be following the rules of physical distancing. As a result, this cannot run optimally like learning in normal times before the pandemic.

Therefore, the researchers collaborated with the school and carried out training and mentoring events for parents, as well as monitoring every Saturday on nature-based independent therapy that parents can provide to their sons and daughters at home easily and practically. Independent therapy is provided side by side with daily online learning activities, as well as therapy activities in schools that are carried out with the COVID19 procedure such 
as ensuring that children, parents, and teachers and therapists are in good physical health, checking body temperature, maintaining body hygiene, especially hands and feet before and during the therapy, keeping distant as much as possible without decreasing the quality of therapy procedures.

Based on the results of measurements carried out on the three research subjects, when parents applied nature-based self-therapy at home, it appeared that adequate positive emotional expressions appeared in their positive expressions such as smiles, enthusiastic expressions, happy expressions, and calm movements. As long as the self-therapy is applied by the parents, the subjects are willing to follow the instructions given and the activities until it is finished.

The emergence of adequate positive emotional expression on the subject is due to the subject's attention and interest in the nature-based self-therapy process. Nature-based learning is given in the form of various outdoor exploration activities. It also provides an opportunity to all senses to come into contact with nature, especially water and land, makes the subject relaxed, but on the other hand, it inspires the nerves at the end of his senses to become more active, and it indirectly activates the work of the central nervous system [23]. In addition to the apparent positive emotional expressions, the subjects also showed an increase in developmental outcomes in several aspects, as presented in the following data.

Table 4. Child Development Outcomes after Nature-based Self Therapy

ASPECT

\begin{tabular}{|c|c|c|c|c|c|c|c|}
\hline & & \multicolumn{2}{|c|}{ АHМ } & \multicolumn{2}{|c|}{ MRAF } & \multicolumn{2}{|c|}{$\mathbf{A A Z}$} \\
\hline & & $\mathrm{A}$ & B & A & B & A & B \\
\hline $\begin{array}{l}\text { Intelligence } \& \\
\text { Capability }\end{array}$ & $\begin{array}{l}\text { Potential intelligence of individuals in } \\
\text { groups of age, which is manifested in the } \\
\text { ability to understand information }\end{array}$ & 4 & 4 & 2 & 2 & 2 & 3 \\
\hline $\begin{array}{l}\text { Language } \\
\text { skills }\end{array}$ & $\begin{array}{l}\text { Understanding instructions, and } \\
\text { expressing thoughts through word }\end{array}$ & 3 & 3 & 2 & 3 & 3 & 3 \\
\hline Sensory Motor & $\begin{array}{l}\text { Ability to move in a strong, flexible, and } \\
\text { balanced muscle coordination }\end{array}$ & 3 & 4 & 2 & 3 & 3 & 3 \\
\hline Independence & Self-help in daily activities & 3 & 3 & 1 & 2 & 2 & 3 \\
\hline Emotion & Express feeling & 3 & 4 & 2 & 3 & 3 & 3 \\
\hline $\begin{array}{c}\text { Social } \\
\text { Relations }\end{array}$ & Build relationships with other people & 4 & 5 & 2 & 3 & 3 & 3 \\
\hline Concentration & Focus attention intensely and attentively & 2 & 3 & 2 & 3 & 3 & 3 \\
\hline $\begin{array}{l}\text { Motivation \& } \\
\text { Confidence }\end{array}$ & Confidence in the potential ability & 4 & 5 & 3 & 3 & 3 & 3 \\
\hline
\end{tabular}

Information: * 1) Not yet developed; 2) Start to appear with limited frequency; 3) Development needs to be motivated, not adequate; 4) Sufficient Development, according to Age; 5) Good development, running optimally; 6) Very good development, skyrocketing above the average age ability. ** A = Month 1 (July), B= Month 2 (August) 
MRAF has the delay problem in the overall developmental function (general developmental delay) caused by complex genetic problems. This problem has an impact on the delay of the subject in all aspects of its development, especially barriers to cognitive, psycho motor, language, and affection (social and emotional) development. In the baseline phase, MRAF has not been able to provide any response and based on its development milestones, it is equivalent to the development of children aged 1 year. It was amazing to find out that MRAF shows a positive response after stimulation, although it is inadequate.

AHM has problems with attention deficit and hyperactivity disorder / ADHD or in other languages is called attention deficit and hyperactivity disorders / ADHD. This disorder causes the subject to have 3 main symptoms, namely, difficulty concentrating, impulsivity, and excess energy which causes the subject to become hyperactive. The subject experienced a significant increase in ability, although the subject's condition did not experience delays or significant problems in the cognitive aspects, the subject experienced a significant increase especially in the subject's language skills and social-emotional abilities.

Down Syndrome experienced by AAZ has an impact on the deterioration of developmental functions, especially on the capacity of intelligence. Various abilities of the subjects developed late below the average ability. This subject experienced many positive changes after being given sensory activities playing in nature. The learning activities given to AAZ are focused on mastery of self-help and daily living activities. In the cognitive aspect, it appears that the subject is able to start absorbing the information around him, the response is good and quite adequate. The subject's psycho motor abilities experienced positive development. The strength and balance of the legs, hands, and body are getting better.

Based on the description above, it can be seen that TB QITA is one of a preschool implemented nature-based learning that was delivered side by side with individual education programs at school by teachers and at home by parents. The activities using nature as the setting and media of the treatment to the children in daily situations emphasized stimulation of the three main senses, namely tactile, vestibular, and proprioceptive.

Those three sensory systems are very important because they help interpret and respond to children's responses to the environment. The tactile system is the largest sensory system formed by receptors in the skin, which send information to the brain for light, touch, pain, temperature, and pressure stimuli. The vestibular system is located in the inner ear (semicircular canal) and detects movement and changes in head position. The vestibular system is the basis of muscle tone, balance, and bilateral coordination. The proprioceptive system is found in muscle fibers, tendons, and ligaments, which allows children to unconsciously know the position and movement of the body [23][24].

Ultimately, there are several pivotal elements in nature-based learning that affected significantly on the psychological well-being of subjects, as well as the increase of their developmental achievement, as follows:

1) Learning is carried out outside the room (outdoor) and in nature, thus it can provide flexibility for children to move and to explore.

2) Learning uses the media of various objects in nature with all the characters they have and the sensations they cause. This nature-based learning allows children to come into contact directly and feel various natural sensations such as heat, cold, the glare of the sun, gravel that makes the feet tickle or a little sore, grass that makes itchy or perhaps also soft and comfortable, water, soil, dew, and various objects in nature along with the sensations they cause. 
3) Learning in nature provides an opportunity for all senses that children have to capture much diverse information so that it stimulates the central nerve to respond more actively. As a result, children can be more responsive.

4) Learning in nature allows for an atmosphere of peacefulness and serenity created by nature and various existing media. Even though the activities are carried out in interesting situations, they still make children calm, making it easier for them to be cooperative, comfortable, and secured.

5) Learning in nature is carried out by teachers who are able to facilitate appropriate and adequate learning activities and have good class mastery.

6) Learning in nature allows children to communicate with each other and interact with their peers more comfortably and freely.

\section{Conclusion}

This research was conducted during the 4 months period, starting from February to August 2020, in one of a preschool using nature as the setting and media of the learning activities. The nature-based learning gave a positive impact on the psychological well-being of children with special needs. The significant impact was indicated by the emergence of positive affection, rather than the negative emotion. The ability to express affection, and the emergence of the positive emotion increased adequately and more precisely. The implementation of nature-based learning gave a positive impact on the children's developmental milestone. Either parents or teachers agreed students felt comfortable with the setting of learning activities in nature. It made the children feel happier, it also could relieve the tension particularly between parents and children during activities. The ability of the children in many aspects of their development increased gradually, and it helps the children to explore their potential. The nature-based learning could be developed and applied widely in the community, based on the reason for its effectiveness, its accessible process and requirements.

\section{References}

[1] Hallahan, D. P \& Kauffman, J. M. 1988. Exeptional Children. New Jersey: Prentice Hall 1

[2] Hallahan, D.P \& Kauffman, J.M. 2011. Handbook of Special Education. New York : Routledge 2

[3] Winarsih, Sri. 2013. Panduan Penanganan Anak Berkebutuhan Khusus bagi Pendamping : Orang Tua, Keluarga, dan Masyarakat. Jakarta : The Ministry of Women's Empowerment and Child Protection Republic Indonesia

[4] Kementerian Kesehatan RI. 2014. Penyandang Disabilitas pada Anak. InfoDATIN, Pusat Data dan Informasi Kementerian Kesehatan RI. Jakarta : The Ministry of Health Republic Indonesia

[5] Hapsari, M.I. 2015. Identifikasi Permasalahan Anak Usia Dini Berkebutuhan Khusus dan Penanganannya. Jurnal Psychoidea. Vol 13, No 1.

[6] Diagnostic and Statistical Manual of Mental Disorders (DSM-V). 1994. New York : American Psychiatric Association.

[7] Connellan, Kathleen. Due, Clemence. Riggs, Damien. 2011. Gardens of The Mind: Nature, Power and Design for Mental Health. Proceeding of IASDR 2011. The Netherlands: The 4th World Conference on Design Research-Diversity and Unity.

[8] Coley, J. D. 2012. Where the wild things are: Informal experience and ecological reasoning. Child Development, 83, 992-1006

[9] Flouri, E., Midouhas, E., \& Joshi, H. 2014. The role of urban neighbourhood green space in children's emotional and behavioural resilience. Journal of Environmental Psychology, 40, 179186. 
[10] Gill, T. 2014. The benefits of children's engagement with nature: A systematic literature review. Children Youth and Environments, 24, 10-34.

[11] Chawla, L. 2015. Benefits of nature contact for children. Journal of Planning SLiterature, 30, 433452

[12] Evans, G. W. 2006. Child development and the physical environment. Annual Review of Psychology, 57, 423-451.

[13] Bekkhus, Mona. Vitaro, Frank. Ulset, Vidar. Brendgen, Mara. 2017. Time spent outdoors during preschool: Links with children's cognitive and behavioral development. Journal of Environmental Psychology 52 . June 2017

[14] Gattis, Meredith. Melville, Joanna. 2018. Responding to Nature: Natural Environments Improve Parent-Child Communication. Journal of Environmental Psychology. August 2018

[15] Yeni Rachmawati dan Euis Kurniati. 2010. Strategi Pengembangan Kreativitas Pada Anak Usia Taman Kanak-kanak. Jakarta: Kencana Prenada Media Group.

[16] Piaget, J. 1985. The Equilibration of Cognitive Structures. Chicago : The University of Chicago Press.

[17] Direktorat Pembinaan Pendidikan Anak Usia Dini. 2014. Kerangka Dasar dan Struktur Kurikulum 2013 Pendidikan Anak Usia Dini. Jakarta : Ministry of Education and Culture.

[18] National Association for The Education of Young Children. 2009. Developmentally Appropriate Practice in Early Childhood Programs Serving Children from Birth through Age 8. www.naeyc.org.

[19] Hurlock, Elizabeth B. 1993. Psikologi Perkembangan Anak, Jilid 2. Jakarta : Airlangga

[20] Santrock, John W. 2002. Life-span Development : Perkembangan Masa Hidup. Edisi 5 Jilid 2. Jakarta : Erlangga.

[21] Davis, J. 1998. The Transpersonal Dimensions of Eco-psychology: Nature, Nonduality, and Spiritual Practice. The Humanistic Psychologist, 26(1-3), 60-100

[22] Dietrich, K. 2005. Principles and Practices of Neurodevelopmental Assessment in Children: Lessons Learned from The Centers for Children's Environmental Health and Disease Prevention Research. Environmental Health Perspective. 113(10):1437-1446.

[23] Ruffin, Novela J. 2009. Understanding Growth and Development Patterns of Infants. Virginia State University. Publication 350-055.

[24] Berger, R., McLeod, J. 2006. Incorporating nature into therapy: A framework for practice. Journal of Systemic Therapies, 25(2), 80-94. 